\title{
PENGARUH VOLUME PENJUALAN TERHADAP PAJAK PERTAMBAHAN NILAI PADA PT JAWA ELECTRIC PRIMA JAKARTA
}

\author{
Sabil ${ }^{1}$ \\ sabil.sbl@bsi.ac.id \\ Fildzah Ghassani ${ }^{2}$ \\ ghassanifildzah8@gmail.com \\ Suhartono ${ }^{3}$ \\ suhartono.sht@bsi.ac.id \\ Lukman Hakim 4 \\ lukman.Imh@bsi.ac.id \\ Program Studi Administrasi Bisnis, Fakultas Ekononomi dan Bisnis 1,2,3,4 \\ Universitas Bina Sarana Informatika Jakarta \\ Jl. Kamal Raya No.18, Ring Road Barat, Cengkareng,Jakarta
}

\begin{abstract}
The purpose of this study is to examine the effect of sales volume on value added tax using quantitative research methods. Data analysis used statistical correlation analysis tests, coefficient of determination, and regression equations, with sales volume as an independent variable $(X)$ and Value Added Tax as the dependent variable $(Y)$. The results showed that the correlation value was 0.628 which means the relationship between the two variables was strong. While the coefficient of determination $R 2$ is $39.4 \%$, which means that the independent variable, namely sales volume $(X)$, has the effect of contributing $39.4 \%$ to the dependent variable, namely VAT $(Y)$ and the remaining $60.6 \%$ is influenced by other variables. From the results of testing the regression equation $Y=15.251+0.418 X$, the significant level of the simple linear regression equation is from the output sig. (2-tailed) is 0,000. Because the probability is below $0.05(0,000<0.05)$, which means that the regression equation is significant between sales volume $(X)$ and value added tax $(Y)$.
\end{abstract}

Keywords: Sales Volume, Value Added Tax.

Abstrak

Tujuan dari penelitian ini adalah untuk menguji pengaruh volume penjualan terhadap Pajak Pertambahan Nilai dengan menggunakan metode penelitian kuantitatif. Analisis data menggunakan uji analisis statistik korelasi, koefisien determinasi, dan persamaan regresi, dengan volume penjualan sebagai variabel independen $(X)$ dan Pajak Pertambahan Nilai sebagai variabel dependen $(Y)$. Hasil penelitian menunjukkan bahwa nilai korelasi 0,628 yang berarti hubungan antara dua variabel kuat. Sedangkan koefisien determinasi R2 adalah 39,4\% yang artinya bahwa variabel independen yaitu volume penjualan (X) memiliki pengaruh kontribusi 39,4\% terhadap variabel dependen yaitu PPN (Y) dan sisanya 60,6\% dipengaruhi oleh variabel lain. Dari hasil pengujian persamaan regresi $Y=15.251+0,418 X$, tingkat signifikan persamaan regresi linier sederhana dari output sig. (2-tailed) adalah 0,000. Karena probabilitas di bawah $0,05(0,000<0,05)$ yang berarti persamaan regresi signifikan antara volume penjualan $(X)$ dengan Pajak Pertambahan Nilai $(Y)$.

Kata Kunci: Volume Penjualan, Pajak Pertambahan Nilai.

\section{PENDAHULUAN}

Pembangunan nasional yang merata dan menyeluruh sangat di dambakan masyarakat Indonesia. Untuk itu diperlukan dana yang sangat besar. Salah satunya adalah melalui penerimaan dari sektor pajak. Salah satu dampak positif dari persaingan usaha yang sangat ketat adalah konsumen dapat memilih memilih kualitas dan harga produk, yang pada akhirnya mempengaruhi tingkat volume penjualan. Meningkatnya volume penjualan suatu perusahaan merupakan indikator dari kemajuan perusahaan. Dalam setiap transaksi penjualan dan pembelian, terdapat Pajak Pertambahan Nilai (PPN) yang mengakibatkan besarnya penjualan atau pembelian suatu barang dapat berpengaruh terhadap besarnya Pajak Pertambahan Nilai terutang. Setiap penyerahan BKP (Barang Kena Pajak) atau JKP (Jasa Kena Pajak) kepada lawan transaksi, akan dikenakan Pajak Pertambahan Nilai sebesar $10 \%$ di setiap barang dan jasa. PT Jawa Electric Prima sebagai supplier dan berlawan transaksi yang sudah menjadi PKP, barang-barang yang dijual termasuk BKP dan pembayarannya secara kredit dan tunai sehingga setiap barang yang dijual di PT Jawa Electric Prima dikenakan PPN. 


\section{TINJAUAN PUSTAKA / KAJIAN TEORITIS}

\section{Pengertian Volume Penjualan}

Menurut Daryono dalam (Risyana \& Suzan, 2018) yaitu ukuran yang menunjukan banyaknya jumlah barang. Menurut Winardi dalam (Saragih, 2017) "Volume penjualan adalah hasil penjualan yang dinyatakan dalam bentuk kualitatif, fiskal, atau volume."

\section{Pengertian Penjualan}

Menurut Mulyadi dalam (Hartanti, 2016) yaitu kegiatan yang dilakukan dalam menjual barang atau jasa dengan harapan akan memperoleh keuntungan.

\section{Jenis-Jenis Penjualan}

1. Trade Selling

Jenis-jenis penjualan menurut Swastha dan Irawan dalam (Hartanti, 2016) sebagai berikut:

2. Missionary Selling

Penjualan berusaha ditingkatkan dengan mendorong pembeli untuk membeli barang dari penyalur perushaan.

3. Technical Selling

4. New Business Selling

5. Responsive Selling

Menurut Mijan dalam (Hartanti, 2016) menjelaskan bahwa terdapat berbagai macam transaksi penjualan yang dapat diklasifikasikan sebagai berikut:

1. Penjualan secara tunai

2. Penjualan kredit

3. Penjualan secara tender

4. Penjualan ekspor

5. Penjualan secara konsinyasi

6. Penjualan secara grosir Penjualan yang dilakukan tidak langsung kepada pembeli, tetapi melalui pedagang perantara yang menjadi perantara pabrik atau importer dengan pedagang eceran.

\section{Dokumen-Dokumen Penjualan}

Menurut Midjan dalam (Wijaya \& Irawan, 2018) yaitu :

1. Order Penjualan (Sales Order)

2. Nota Penjualan Barang

3. Perintah Penyerahan Barang (Delivery Order)

4. Faktur Penjualan (Invoice)

Adalah dokumen yang menunjukan jumlah yang berhak ditagih kepada pelanggan yang menunjukan informasi kuantititas, harga dan jumlah tagihan.

5. Surat Pengiriman Barang (Shipping Slip)

6. Jurnal Penjulan (Sales Journal)

\section{Faktor-faktor yang Mempengaruhi Volume Penjualan}

Menurut Nitisemilo dalam (Makmur, 2015), produsen harus memperhatikan berbagai macam faktor yang sangat mempengaruhi dalam volume penjualan seperti :

1. Faktor Internal
a. Kualitas Produksi
b. Service yang diberikan
c. Sering kosongnya barang dipasaran
d. Penurunan kegiatan sales promotion
e. Adanya penetapan harga

2. Faktor Eksternal
a. Perubahan selera konsumen
b. Munculnya saingan baru
c. Munculnya barang pengganti 
d. Pengaruh faktor psychology

e. Perubahan baru dalam kebijkasanaan Pemerintah

f. Kemungkinan adanya tindakan dari pesaing.

\section{Pajak Pertambahan Nilai}

Pengertian Pajak Pertambahan Nilai

Menurut Muljono dalam (Hartanti, 2015) yaitu nilai tambah yang harus dibayarkan oleh konsumen.

\section{Syarat-syarat PPN Terutang}

Menurut (Salman, 2017), terdapat 5 (lima) syarat yang harus ada agar PPN dapat terutang adalah:

1. Adanya suatu penyerahan kena pajak.

2. Sesuatu yang diserahkan adalah BKP atau JKP.

3. Yang menyerahkan adalah PKP atau pengusaha yang memilih untuk dikukuhkan menjadi PKP.Batasan pengusaha kecil yang melakukan penyerahan BKP atau JKP setahun tidak lebih dari Rp 600 Juta. Jika sampai suatu bulan tahun suatu tahun jumlahnya melebihi Rp 600 Juta, maka wajib mengukuhkan PKP paling lambat pada akhir bulan berikutnya.

4. Dilakukan di dalam Daerah Pabean.

\section{Karakteristik Pajak Pertambahan Nilai}

Karakteristik Pajak Pertambahan Nilai Indonesia menurut Sukardji dalam (Riftiasari, 2019) dapat dirinci sebagai berikut:

1. Pajak Pertambahan Nilai merupakan pajak tidak langsung.

2. Pajak objektif.

3. Multi Stage Tax.

4. PPN terutang untuk dibayar ke kas negara dihitung menggunakan indirect subcration method atau credit method atau invoice method.

5. Setiap transaksi di Indonesia.

6. Pajak Pertambahan Nilali bersifat netral.

7. Tidak menimbulkan dampak pengenaan pajak berganda.

\section{Subjek Pajak Pertambahan Nilai}

Menurut Priantara dalam (Riftiasari, 2019) subjek PPN yang bertanggung jawab terhadap pemungutan, penyetoran, dan pelaporan PPN adalah:

1. Pengusaha

2. Pengusaha Kena Pajak (PKP)

Adalah pengusaha yang melakukan penyerahan BKP dan atau JKP yang dikenakan pajak berdasarkan UU PPN, tidak termasuk pengusaha kecil yang batasannya ditetapkan dengan keputusan Menteri Keuangan.

3. Bukan PKP

\section{Dasar Pengenaan Pajak Pertambahan Nilai}

Menurut (Salman, 2017) ditentukan beberapa Dasar Pengenaan Pajak (DPP) dari PPN. Berikut akan dijelaskan beberapa DPP dari PPN yaitu:

1. Harga Jual

2. Penggantian

3. Nilai Impor

4. Nilai Ekspor

5. Nilai lain

\section{Tarif Pajak Pertambahan Nilai}

Menurut (Salman, 2017) yaitu yang terutang dihitung dengan cara mengalikan Tarif Pajak dengan

Dasar Pengenaan Pajak (DPP). 


\section{Mekanisme Pengenaan PPN} sebagai berikut:

Menurut (Mardiasmo, 2018) Mekanisme pengenaan Pajak Pertambahan Nilai dapat digambarkan

1. Pada saat membeli atau memperoleh BKP/JKP, akan dipungut PPN oleh PKP penjual.

2. Saat menjual atau menyerahkan BKP atau JKP kepada konsumen

3. Selisihnya harus disetorkan ke kas negara.

4. Pelaporan menggunakan Surat Pemberitahuan Masa Pajak Pertambahan Nilai (SPT Masa PPN).

\section{METODE PENELITIAN}

Penelitian dilakukan selama 3 (tiga) bulan yaitu dari bulan April sampai Juni 2019 dengan objek penelitian yaitu PT Jawa Electric Prima Jakarta.. Metode yang digunakan dalam penelitian ini adalah kuantitatif dengan data primer dan sekunder. Analisis data menggunakan uji analisis statistik korelasi, koefisien determinasi, dan persamaan regresi, dengan Volume Penjualan sebagai variabel independen $(X)$ dan Pajak Pertambahan Nilai sebagai variabel dependen (Y).

\section{HASIL PENELITIAN}

\section{REKAPITULASI VOLUME PENJUALAN}

Berikut ini data volume penjualan pada PT Jawa Electric Prima pada tahun 2016 sampai dengan tahun 2018.

Tabel 1

\section{Data Volume Penjualan PT Jawa Electric Prima}

\begin{tabular}{|c|c|c|c|c|}
\hline \multirow{2}{*}{ No } & \multirow{2}{*}{ Bulan } & \multicolumn{3}{|c|}{ Volume (Meter) } \\
\hline & & Tahun 2016 & Tahun 2017 & Tahun 2018 \\
\hline 1 & Januari & 513.714 & 608.160 & 251.940 \\
\hline 2 & Februari & 401.837 & 414.507 & 176.690 \\
\hline 3 & Maret & 469.023 & 389.905 & 224.040 \\
\hline 4 & April & 364.770 & 327.052 & 293.283 \\
\hline 5 & Mei & 377.830 & 325.262 & 263.078 \\
\hline 6 & Juni & 470.564 & 251.507 & 189.283 \\
\hline 7 & Juli & 180.682 & 323.124 & 220.633 \\
\hline 8 & Agustus & 370.798 & 406.727 & 202.266 \\
\hline 9 & September & 614.269 & 326.969 & 278.797 \\
\hline 10 & Oktober & 537.411 & 273.914 & 266.643 \\
\hline 11 & Nopember & 1.041 .609 & 386.923 & 299.416 \\
\hline 12 & Desember & 521.752 & 230.928 & 220.846 \\
\hline & Jumlah & 5.864 .259 & 4.264 .978 & 2.886 .915 \\
\hline
\end{tabular}

Sumber: PT Jawa Electric Prima

Berdasarkan tabel 1 dapat dilihat bahwa adanya penurunan volume penjualan dari tahun ke tahun, terlihat dari tahun 2016 ke tahun 2017 mengalami penurunan volume penjualan sebanyak 1.599.281 meter. Kemudian tahun 2017 ke tahun 2018 mengalami penurunan sebanyak 1.378 .063 meter. Sepinya pembeli menjadi penyebabnya, karena setiap tahun selalu mengalami kenaikan harga dari pabrik sehingga perusahaan pun ikut menaikan harga jual, stok tidak selalu siap dan sering kosong ketika pelanggan ingin memesan. 
Data Pajak Pertambahan Nilai (Y)

Berikut ini rekapitulasin Pajak Pertambahan Nilai keluaran pada PT Jawa Electric Prima pada tahun 2016 sampai dengan tahun 2018.

Tabel 2

Rekapitulasi Pajak Pertambahan Nilai Keluaran PT Jawa Electric Prima

\begin{tabular}{|c|c|c|c|c|}
\hline \multirow{2}{*}{ No } & \multirow{2}{*}{ Bulan } & \multicolumn{3}{|c|}{ Nominal (Rupiah) } \\
\hline & & Tahun 2016 & Tahun 2017 & Tahun 2018 \\
\hline 1 & Januari & 1.086 .346 .573 & 1.093.097.103 & 1.014 .641 .834 \\
\hline 2 & Februari & 819.371 .593 & 754.267 .872 & 705.660 .096 \\
\hline 3 & Maret & 973.382 .557 & 820.853 .306 & 650.994 .991 \\
\hline 4 & April & 803.856 .821 & 621.605 .516 & 991.315 .200 \\
\hline 5 & Mei & 818.873 .299 & 1.048 .584 .305 & 739.594 .979 \\
\hline 6 & Juni & 1.248 .572 .412 & 488.043 .415 & 507.676 .166 \\
\hline 7 & Juli & 568.538 .550 & 701.063 .613 & 847.761 .200 \\
\hline 8 & Agustus & 816.236 .566 & 1.025 .880 .097 & 642.204 .966 \\
\hline 9 & September & 1.157 .869 .164 & 701.216 .944 & 981.229 .813 \\
\hline 10 & Oktober & 1.196 .341 .824 & 1.185 .090 .734 & 1.041 .863 .300 \\
\hline 11 & Nopember & 1.322 .436 .945 & 887.593 .320 & 1.386 .497 .974 \\
\hline 12 & Desember & 911.738.723 & 749.539 .199 & 718.417.249 \\
\hline & Jumlah & 11.723 .565 .027 & 10.076 .835 .424 & 10.227 .857 .768 \\
\hline
\end{tabular}

Sumber: PT Jawa Electric Prima

Berdasarkan tabel 1 diketahui bahwa pada tahun 2017 Pajak Pertambahan Nilai mengalami penurunan sebesar Rp 1.646.729.634,-. Dapat terlihat di tahun 2018 Pajak Pertambahan Nilai meningkat sebesar Rp 151.022.338,-- Menurunnya Pajak Pertambahan Nilai pada tahun 2017 disebabkan karena volume penjualan menurun dan kabel-kabel yang terjual hanya kabel yang berdiameter kecil sedangkan pada tahun 2018 Pajak Pertambahan Nilai meningkat (meskipun volume penjualan menurun karena harga pada setiap kabel berbeda), di tahun 2018 pelanggan banyak memesan kabel diameter besar dan harganya pun semakin mahal.

Dibawah ini adalah tabel perbandingan volume penjualan terhadap Pajak Pertambahan Nilai yang disajikan dengan data yang telah di Loan kan (LN) dengan menggunakan Microsoft Excel.

Tabel 3

Data Variabel $X$ dan $Y$ yang telah disederhanakan

\begin{tabular}{lcccccc}
\hline \multirow{2}{*}{ Periode } & \multicolumn{3}{c}{ Data Volume Penjualan } & \multicolumn{3}{c}{ Data Pajak Pertambahan Nilai } \\
\cline { 2 - 7 } & $\mathbf{2 0 1 6}$ & $\mathbf{2 0 1 7}$ & $\mathbf{2 0 1 8}$ & $\mathbf{2 0 1 6}$ & $\mathbf{2 0 1 7}$ & $\mathbf{2 0 1 8}$ \\
\hline Januari & 13,15 & 13,32 & 12,44 & 20,81 & 20,81 & 20,74 \\
\hline Februari & 12,90 & 12,93 & 12,08 & 20,52 & 20,44 & 20,37 \\
\hline Maret & 13,06 & 12,87 & 12,32 & 20,70 & 20,53 & 20,29 \\
\hline April & 12,81 & 12,70 & 12,59 & 20,50 & 20,25 & 20,71 \\
\hline Mei & 12,84 & 12,69 & 12,48 & 20,52 & 20,77 & 20,42 \\
\hline Juni & 13,06 & 12,44 & 12,15 & 20,95 & 20,01 & 20,05 \\
\hline Juli & 12,10 & 12,69 & 12,30 & 20,16 & 20,37 & 20,56 \\
\hline Agustus & 12,82 & 12,92 & 12,22 & 20,52 & 20,75 & 20,28 \\
\hline September & 13,33 & 12,70 & 12,54 & 20,87 & 20,37 & 20,70 \\
\hline Oktober & 13,19 & 12,52 & 12,49 & 20,90 & 20,89 & 20,76 \\
\hline Nopember & 13,86 & 12,87 & 12,61 & 21,00 & 20,60 & 21,05 \\
\hline Desember & 13,16 & 12,35 & 12,31 & 20,63 & 20,43 & 20,39 \\
\hline Data Diolah, 2019 & & & & & &
\end{tabular}




\section{Tabel Penolong}

Untuk memudahkan peneliti dalam melakukan analisis data baik manual maupun menggunakan program aplikasi IBM SPSS versi 20.

Tabel 4

Ringkasan Tabel Penolong

\begin{tabular}{|c|c|c|c|c|c|}
\hline Periode & $X$ & $Y$ & $X Y$ & $X^{2}$ & $Y^{2}$ \\
\hline Jan-16 & 13,15 & 20,81 & 273,588 & 172,907 & 432,893 \\
\hline Feb-16 & 12,90 & 20,52 & 264,838 & 166,508 & 421,237 \\
\hline Mar-16 & 13,06 & 20,70 & 270,261 & 170,522 & 428,336 \\
\hline Apr-16 & 12,81 & 20,50 & 262,607 & 164,020 & 420,452 \\
\hline Mei-16 & 12,84 & 20,52 & 263,566 & 164,922 & 421,212 \\
\hline Jun-16 & 13,06 & 20,95 & 273,581 & 170,608 & 438,704 \\
\hline Jul-16 & 12,10 & 20,16 & 244,009 & 146,519 & 406,368 \\
\hline Agu-16 & 12,82 & 20,52 & 263,139 & 164,440 & 421,079 \\
\hline Sep-16 & 13,33 & 20,87 & 278,157 & 177,641 & 435,551 \\
\hline Okt-16 & 13,19 & 20,90 & 275,799 & 174,095 & 436,916 \\
\hline Nov-16 & 13,86 & 21,00 & 291,020 & 191,996 & 441,115 \\
\hline Des-16 & 13,16 & 20,63 & 271,604 & 173,316 & 425,633 \\
\hline Jan-17 & 13,32 & 20,81 & 277,182 & 177,374 & 433,151 \\
\hline Feb-17 & 12,93 & 20,44 & 264,405 & 167,310 & 417,845 \\
\hline Mar-17 & 12,87 & 20,53 & 264,243 & 165,731 & 421,311 \\
\hline Apr-17 & 12,70 & 20,25 & 257,104 & 161,236 & 409,974 \\
\hline Mei-17 & 12,69 & 20,77 & 263,630 & 161,097 & 431,422 \\
\hline Jun-17 & 12,44 & 20,01 & 248,778 & 154,635 & 400,237 \\
\hline Jul-17 & 12,69 & 20,37 & 258,386 & 160,929 & 414,860 \\
\hline Agu-17 & 12,92 & 20,75 & 267,990 & 166,820 & 430,513 \\
\hline Sept-17 & 12,70 & 20,37 & 258,629 & 161,230 & 414,869 \\
\hline Okt-17 & 12,52 & 20,89 & 261,593 & 156,765 & 436,521 \\
\hline Nov-17 & 12,87 & 20,60 & 265,091 & 165,533 & 424,526 \\
\hline Des-17 & 12,35 & 20,43 & 252,369 & 152,519 & 417,588 \\
\hline Jan-18 & 12,44 & 20,74 & 257,915 & 154,678 & 430,056 \\
\hline Feb-18 & 12,08 & 20,37 & 246,170 & 145,978 & 415,126 \\
\hline Mar-18 & 12,32 & 20,29 & 250,014 & 151,772 & 411,847 \\
\hline Apr-18 & 12,59 & 20,71 & 260,773 & 158,480 & 429,092 \\
\hline Mei-18 & 12,48 & 20,42 & 254,866 & 155,756 & 417,042 \\
\hline Jun-18 & 12,15 & 20,05 & 243,571 & 147,647 & 401,816 \\
\hline Jul-18 & 12,30 & 20,56 & 252,952 & 151,395 & 422,636 \\
\hline Agu-18 & 12,22 & 20,28 & 247,773 & 149,263 & 411,295 \\
\hline Sep-18 & 12,54 & 20,70 & 259,596 & 157,207 & 428,669 \\
\hline Okt-18 & 12,49 & 20,76 & 259,422 & 156,092 & 431,155 \\
\hline Nov-18 & 12,61 & 21,05 & 265,432 & 159,002 & 443,104 \\
\hline Des-18 & 12,31 & 20,39 & 250,935 & 151,418 & 415,857 \\
\hline Jumlah & 457,81 & 740,64 & $9.420,987$ & $5.827,361$ & $15.240,009$ \\
\hline
\end{tabular}

Data Diolah, 2019

\section{Analisa Volume Penjualan $(X)$ terhadap Pajak Pertambahan Nilai $(Y)$}

Analisa yang digunakan untuk mengetahui pengaruh variabel bebas $(X)$ terhadap variabel terikat $(Y)$ yaitu menggunakan uji koefisien korelasi yaitu dengan product moment pearson, uji koefisien determinasi, dan persamaan regresi yaitu uji regresi linear sederhana karena hanya mempunyai masing-masing satu variabel $x$ dan y. 
Uji Koefisien Korelasi

Uji koefisien korelasi digunakan untuk mengetahui apakah terdapat hubungan dan bagaimana keeratan hubungan antara variabel independen $(X)$ dan variabel dependen $(Y)$.

Maka hipotesis yang terbentuk:

$\mathrm{H}_{01} \quad$ : Tidak terdapat hubungan yang signifikan antara volume penjualan terhadap

Pajak Pertambahan Nilai.

$\mathrm{H}_{1} \quad$ : Terdapat hubungan yang signifikan antara volume penjualan terhadap Pajak Pertambahan Nilai.

Dengan syarat:

Jika sig $>0,05$ maka $\mathrm{H}_{1}$ ditolak $\mathrm{H}_{01}$ diterima artinya tidak terdapat hubungan.

Jika sig $<0,05$ maka $\mathrm{H}_{1}$ diterima $\mathrm{H}_{01}$ ditolak artinya terdapat hubungan.

Berdasarkan pengolahan data secara manual dan menggunakan SPSS versi 20, maka hasil uji koefisien korelasi dapat dilihat pada tabel berikut:

$$
\begin{aligned}
& r x y=\frac{n\left(\sum X Y\right)-\left(\sum X\right)\left(\sum Y\right)}{\sqrt{\left\{n\left(\sum X^{2}\right)-\left(\sum X\right)^{2}\right\}\left\{n\left(\sum Y^{2}\right)-\left(\sum Y\right)^{2}\right\}}} \\
& r x y=\frac{36(9.420,987)-(457,809)(740,644)}{\sqrt{\left\{36(5.827,361)-(457,809)^{2}\right\}\left\{36(15.240,009)-(740,644)^{2}\right\}}} \\
& r x y=\frac{(339.155,532)-(339.073,627)}{\sqrt{\{(209.785,013)-(209.589,418)\}\{(548.640,321)-(548.553,098)\}}} \\
& r x y=\frac{339.155,532-339.073,627}{\sqrt{(195,594)(87,223)}} \\
& r x y=\frac{82}{\sqrt{17.060,273}} \\
& r x y=\frac{82}{130,615} \\
& r x y=0,62779 \\
& r x y=0,628 \text { (dibulatkan) }
\end{aligned}
$$

Berikut ini merupakan hasil yang didapatkan dengan menggunakan program aplikasi SPSS versi 20.

Tabel 5

Hasil Uji Koefisien Korelasi

\begin{tabular}{llrr}
\hline & \multicolumn{1}{c}{ Correlations } & & \\
\hline & & Volume Penjualan & $\begin{array}{c}\text { PAJAK } \\
\text { PERTAMBAHAN } \\
\text { NILAI }\end{array}$ \\
\hline \multirow{3}{*}{ Volume Penjualan } & Pearson Correlation & 1 &, $628^{* *}$ \\
\cline { 2 - 5 } & Sig. (2-tailed) & 36 &, 000 \\
\cline { 2 - 4 } & $\mathrm{N}$ &, $628^{* *}$ & 36 \\
\hline \multirow{3}{*}{ PAJAK PERTAMBAHAN NILAI } & Pearson Correlation &, 000 & 1 \\
\cline { 2 - 4 } & Sig. (2-tailed) & 36 & 36
\end{tabular}

**. Correlation is significant at the 0.01 level (2-tailed).

Data Diolah, 2019 
Berdasarkan tabel 5 tingkat signifikan sebesar 0,000, yaitu menunjukan bahwa tingkat sig $0,000<0,05$ jadi $\mathrm{H}_{1}$ diterima dan $\mathrm{H}_{01}$ ditolak, dapat disimpulkan bahwa terdapat hubungan yang signifikan antara volume penjualan terhadap Pajak Pertambahan Nilai. Perhitungan secara manual dan pengolahan data menggunakan SPSS versi 20 diperoleh nilai korelasi sebesar 0,628 . Hal ini menunjukan hubungan yang tinggi atau kuat sesuai dengan tabel intrepretasi korelasi. Arah hubungan antar kedua variabel positif tidak ada tanda negatif pada angka 0,628 menunjukan hubungan searah, berarti semakin tinggi volume penjualan cenderung semakin meningkat Pajak Pertambahan Nilai dan demikian pula sebaliknya.

\section{Uji Koefisien Determinasi}

Uji ini digunakan untuk mengetahui besarnya kontribusi pengaruh Volume Penjualan $(X)$ terhadap Pajak Pertambahan Nilai $(Y)$ dalam bentuk persentase. Pada penelitian ini nilai koefisien determinasi yang dipakai adalah $R$ square.

Berikut merupakan uji koefisien determinasi dengan perhitungan manual dan dengan menggunakan program aplikasi IMB SPPS versi 20.

$\mathrm{KD}=\mathrm{r}^{2} \times 100 \%$

$\mathrm{KD}=(0,628)^{2} \times 100 \%$

$\mathrm{KD}=0,394$ atau $39,4 \%$

Hasil yang didapat dengan menggunakan SPSS versi 20 adalah:

Tabel 6

Hasil Uji Determinasi

\begin{tabular}{|c|c|c|c|c|}
\hline \multicolumn{5}{|c|}{ Model Summary } \\
\hline Model & $\mathrm{R}$ & R Square & Adjusted R Square & $\begin{array}{l}\text { Std. Error of the } \\
\text { Estimate }\end{array}$ \\
\hline 1 & ,628a & 394 & 377, & 20733, \\
\hline
\end{tabular}

a. Predictors: (Constant), Volume Penjualan

Data Diolah, 2019

Berdasarkan perhitungan manual dan hasil pengolahan data menggunakan SPSS v.20 pada table 6 diperoleh nilai $R$ Square sebesar 0,394 yang menunjukan Pajak Pertambahan Nilai pada PT Jawa Electric Prima yang dipengerahui oleh volume penjualan sebesar $39,4 \%$ sedangkan sisanya $(100 \%-39,4 \%=60,6 \%)$ dijelaskan oleh faktor lain yang tidak diteliti seperti harga jual.

Untuk mengetahui apakah volume penjualan $(X)$ berpengaruh signifikan terhadap Pajak Pertambahan Nilai $(Y)$ dengan menggunakan uji t, maka hipotesis yang terbentuk sebagai berikut:

$\mathrm{H}_{02}$ : Tidak terdapat pengaruh yang signifikan antara volume penjualan terhadap PAJAK PERTAMBAHAN NILAI. $\mathrm{H}_{2}$ : Terdapat pengaruh yang signifikan antara volume penjualan terhadap PAJAK PERTAMBAHAN NILAI.

Berdasarkan tingkat signifikansinya adalah

1. Apabila nilai signifikansi $<0,05$ maka $\mathrm{H}_{02}$ ditolak dan $\mathrm{H}_{2}$ diterima.

2. Apabila nilai signifikansi $>0,05$ maka $\mathrm{H}_{02}$ diterima dan $\mathrm{H}_{2}$ ditolak.

Kriteria Pengujian:

Jika $t_{\text {hitung }}>\mathrm{t}_{\text {tabel }}$ maka $\mathrm{H}_{2}$ diterima

Jika $\mathrm{t}_{\text {hitung }}<\mathrm{t}_{\text {tabel }}$ maka $\mathrm{H}_{2}$ ditolak

Hasil perhitungan manual uji t (test) dapat dilihat sebagai berikut:

$t_{\text {hitung }}=\frac{\mathrm{r} \sqrt{n-2}}{\sqrt{1-\mathrm{r}^{2}}}$

$t_{\text {hitung }}=\frac{0,628 \sqrt{36-2}}{\sqrt{1-(0,628)^{2}}}$

$t_{\text {hitung }}=\frac{0,628 \sqrt{34}}{\sqrt{1-0,3944}}$

$t_{\text {hitung }}=\frac{0,628(5,83)}{\sqrt{0,606}}$

$t_{\text {hitung }}=\frac{3,66124}{0,778}$ 
$t_{\text {hitung }}=4,7059$

$\mathrm{t}_{\text {hitung }}=4,706$ (dibulatkan)

Hasil menggunakan IBM SPSS Versi 20 adalah sebagai berikut:

Tabel 7

Hasil Uji t (test)

\begin{tabular}{|c|c|c|c|c|c|c|}
\hline \multicolumn{7}{|c|}{ Coefficients $^{\mathrm{a}}$} \\
\hline \multirow[b]{2}{*}{ Model } & & Unstandardize & Coefficients & Standardized & $t$ & Sig. \\
\hline & & B & Std. Error & Beta & & \\
\hline \multirow{2}{*}{1} & (Constant) & 15,251 & 1,131 & & 13,482 &, 000 \\
\hline & Volume Penjualan & ,418 & ,089 & ,628 & 4,706 &, 000 \\
\hline
\end{tabular}

a. Dependent Variable: PAJAK PERTAMBAHAN NILAI

Data Diolah, 2019

Dari tabel 7 diatas diketahui nilai probabilitas 0,000 . Karena signifikansi menggunakan $5 \%$ yaitu $<0,05$ maka keputusannya $\mathrm{H}_{02}$ ditolak dan $\mathrm{H}_{2}$ diterima. Berarti dapat dikatakan bahwa Volume Penjualan berpengaruh secara signifikan terhadap Pajak Pertambahan Nilai.

Berdasarkan hasil uji t pada tabel III.7 diketahui nilai thitung yang nanti akan dibandingkan dengan $t_{\text {tabel }}$. Untuk melihat nilai t hitung ada pada tabel coefficients di kolom t. Untuk menentukan $t_{\text {tabel, }}$, tabel distribusi t dicari pada $\alpha=5 \%: 2=2,5 \%$ (uji 2 sisi) dengan derajat kebebasan (df) $n-k-1$ ( $n$ adalah jumlah data dan $k$ adalah jumlah variabel independen). Dengan pengujian 2 sisi (signifikansi $=0,025)$.

$\mathrm{t}_{\text {tabel }}=(\alpha / 2 ; \mathrm{n}-\mathrm{k}-1)$

$t_{\text {tabel }} \quad=(0,05 / 2 ; 36-1-1)$

$t_{\text {tabel }}=0,025 ; 34$

$t_{\text {tabel }}=2,032$

Berdasarkan perhitungan manual dan pengolaan data menggunakan SPSS pada tabel 7 dapat dilihat pada kolom t nilai volume penjualan adalah 4,706 yang artinya nilai thitung sebesar 4,706. Diketahui thitung pada tabel coefficient sebesar 4,706 sedangkan $t_{\text {tabel }}$ sebesar 2,032.

Berdasarkan table 7 dapat disimpulkan bahwa $t_{\text {hitung }}>t_{\text {tabel }}$ yaitu $(4,706>2,032)$ yang artinya bahwa ada pengaruh yang signifikan antara volume penjualan dengan Pajak Pertambahan Nilai.

\section{Uji Persamaan Regresi}

Pada penelitian ini akan dijelaskan hasil persamaan regresi linier sederhana yang tujuannya adalah untuk melihat bagaimana persamaan regresi yang terbentuk antara Volume Penjualan $(X)$ terhadap Pajak Pertambahan Nilai $(Y)$. Berikut dapat dilihat hasil dari analisis regresi linier sederhana.

$Y=a+b X$

Hipotesis:

$\mathrm{H}_{03}$ : Persamaan regresi yang terbentuk tidak signifikan.

$\mathrm{H}_{3}$ : Persamaan regresi yang terbentuksignifikan.

Dengan syarat:

Jika sig >0,05 maka $\mathrm{H}_{03}$ diterima dan $\mathrm{H}_{3}$ ditolak

Jika sig $<0,05$ maka $\mathrm{H}_{03}$ ditolak dan $\mathrm{H}_{3}$ diterima

Berikut perhitungan manual untuk mencari persamaan regresi yang terbentuk antara Volume Penjualan dan Pajak Pertambahan Nilai pada PT Jawa Electric Pima.

1. Mencari nilai a

$$
\begin{aligned}
& \alpha=\frac{\left(\sum y\right)\left(\sum x^{2}\right)-\left(\sum x\right)\left(\sum x y\right)}{n\left(\sum x^{2}\right)-\left(\sum x\right)^{2}} \\
& \alpha=\frac{(740.64)(5.827,361)-(457,81)(9.420,987)}{36(5.827,361)-(209.589,42)} \\
& \alpha=\frac{(4.315 .998,591)-(4.313 .016,115)}{(209.785,01)-(209.589,42)}
\end{aligned}
$$




$$
\begin{aligned}
& \alpha=\frac{(2.982,476)}{(195,59)} \\
& \alpha=15,251
\end{aligned}
$$

2. Mencari nilai $b$

$$
\begin{aligned}
\mathrm{b} & =\frac{n \sum x y-\sum x \sum y}{n \sum x^{2}-\left(\sum x\right)^{2}} \\
\mathrm{~b} & =\frac{36(9.420,987)-(457,81)(740,64)}{36(5.827,361)-(209.589,42)} \\
\mathrm{b} & =\frac{(339.155,53)-(339.073,63)}{(209.785,01)-(209.589,42)} \\
\mathrm{b} & =\frac{82}{196} \\
\mathrm{~b} & =0,418
\end{aligned}
$$

\begin{tabular}{|c|c|c|c|c|c|c|}
\hline \multicolumn{7}{|c|}{ Coefficients $^{a}$} \\
\hline & & $\begin{array}{r}\text { Unstan } \\
\text { Coeff }\end{array}$ & $\begin{array}{l}\text { ardized } \\
\text { ients }\end{array}$ & $\begin{array}{l}\text { Standardized } \\
\text { Coefficients }\end{array}$ & T & Sig. \\
\hline \multicolumn{7}{|c|}{ Model } \\
\hline \multirow{2}{*}{1} & (Constant) & 15,251 & 1,131 & & 13,482 &, 000 \\
\hline & Volume Penjualan & ,418 & ,089 & 628 & 4,706 &, 000 \\
\hline
\end{tabular}

Dari perhitungan diatas, maka persamaan yang didapat untuk regresi liniear adalah $Y=15,251+0,418$ $X$, hasil tersebut sama dengan perhitungan dengan menggunakan IBM SPSS versi 20 yang akan dijelaskan sebagai berikut:

\section{Tabel 8}

Hasil Uji Persamaan Regresi

a. Dependent Variable: PAJAK PERTAMBAHAN NILAI

\section{Data Diolah, 2019}

Pada tabel.8 diketahui nilai konstanta a sebesar 15,251 dan nilai koefisien $b$ adalah 0,418 maka dapat diperoleh bentuk persamaan regresi linier sederhana yaitu: $Y=15,251+0,418 X$

Persamaan yang berentuk dari hasil uji regresi linier sederhana menggunakan IBM SPSS versi 20 sama dengan persamaan yang didapat oleh penulis berdasarkan perhitungan manual yang sudah dibahas. Pada persamaan regresi tersebut dapat ditarik kesimpulan berikut:

1. Nilai konstanta $a=15,251$ dapat diartikan jika volume penjualan $(X)$ nilainya 0 (nol) maka Pajak Pertambahan Nilai (Y) adalah 15,251.

2. Nilai koefisien b sebesar 0,418 yang menunjukan arah positif yang berarti mengalami peningkatan, artinya jika volume penjualan $(X)$ mengalami kenaikan $1 \%$, maka Pajak Pertambahan Nilai $(Y)$ akan mengalami peningkatan sebesar $0,418 \%$.

3. Tingkat signifikan Persamaan Regresi Linier Sederhana dari outputsig (2-tailed) diukur dari probabilitas menghasilkan angka 0,000. Dengan kriteria signifikan yaitu $0,05(0,000<0,05)$ maka $\mathrm{H}_{03}$ ditolak dan $\mathrm{H}_{3}$ diterima yang berarti dapat disimpulkan jika model persamaan regresi yang terbentuk pada data penelitian tersebut signifikan.

\section{PEMBAHASAN}

Hasil penelitian menunjukkan bahwa ada pengaruh yang signifikan antara volume penjualan $(X)$ dengan Pajak Pertambahan Nilai (Y) pada PT. Jawa Electric Prima Jakarta tahun 2016 - 2018. Hasil penelitian ini sesuai dengan hasil penelitian dari (Rustami, Kirya, \& Cipta, 2014)yang menyatakan bahwa variabel yang paling dominan mempengaruhi besarnya laba pada Perusahaan Kopi Bubuk Banyuatis Singaraja adalah volume penjualan. Hasil penelitian ini juga sejalan dengan peneitian (Dewinta \& Setiawan, 2016) yang menyatakan bahwa pertumbuhan penjualan berpengaruh positif terhadap tax avoidance.

Data dari hasil penelitian berkaitan dengan teori yang digunakan yaitu menurut (Salman, 2017) ditentukan beberapa Dasar Pengenaan Pajak dari Pajak Pertambahan Nilai. Maka hasil pengenaan pajak yang 
dijalankan oleh PT Jawa Electric Prima Jakarta seuai derngan teori yang digunakan yaitu jumlah penjualan akan berpengaruh kepada jumlah Pajak Pertambahan Nilai yang yang disetor atau yang dilaporkan. Apabila dikaitan dengan kondisi yang ada pada saat ini maka PT Jawa Electric Prima Jakarta mengikuti undang-undang perpajakan yang berlaku di Indonesia. Sementara Hipotesa setelah dilakukan perhitungan maka terdapat hubungan antara penjualan dengan jumlah Pajak Pertambahan Nilai yang dilaporkan yaitu semakin banyak jumlah barang yang terjual maka jumlah nilai Pajak Pertambahan Nilai yang dilaporkan juga akan meningkat.

Penelitian terdahulu tidak membahas secara kuantitatif akan tetapi secara kualitatif sehingga hanya mengetahui pengenaan pajak dari penjualan, sementara penelitian sekarang ini membahas secara kuantitaif dengan mengetahui hubungan antara penjualan dengan jumlah PPN secara statistik serta menggunakan hipotesa untuk mengetahui hubungan dengan ditunjukkan apakah signifikan atau tidak. Dari hasil perhitungan menunjukkan bahwa terdapat yang signifikan antara volume penjualan $(X)$ dengan Pajak Pertambahan Nilai $(Y)$.

\section{SIMPULAN DAN SARAN}

Berdasarkan pengujian hipotesis yang memberikan hasil bahwa terdapat hubungan/korelasi yang sangat kuat antara volume penjualan terhadap Pajak Pertambahan Nilai sebesar 4,706. Dimana berdasarkan hasil perhitungan nilai "t" hitung dengan menggunakan SPSS adalah dengan uji $t$ di peroleh $t_{\text {hitung }}>t_{\text {tabel }}$ yaitu $(4,706>2,032)$ maka $\mathrm{H}_{0}$ ditolak dan $\mathrm{H}_{\mathrm{a}}$ diterima dapat dilihat pada kolom t nilai volume penjualan adalah yang artinya nilai thitung sebesar 4,706. Diketahui thitung pada tabel coefficient sebesar 4,706 sedangkan tabel sebesar 2,032. Artinya bahwa ada pengaruh secara signifikan antara volume penjualan dengan Pajak Pertambahan Nilai.

Sebaiknya penelitian lebih lanjut dapat menambah variable lainnya seperti kompensasi, restitusi pajak pertambahan nilai dan lain-lain.

\section{DAFTAR PUSTAKA}

Dewinta, I. A. R., \& Setiawan, P. E. (2016). Pengaruh Ukuran Perusahaan, Umur Perusahaan, Profitabilitas, Leverage, Dan Pertumbuhan Penjualan Terhadap Tax Avoidance. E-Jurnal Akuntansi Universitas Udayana, 14(3), 1584-1613.

Hartanti. (2016). Pengaruh Biaya Produksi Terhadap Penjualan Pada Pt. Shindengen Indonesia. III, 85.

Hartanti, H. (2015). Implementasi Surat Edaran Direktur Pajak Nomor Se-24 /Pj/2014: Pajak Pertambahan Nilai Atas Barang Hasil Pertanian (Studi Kasus Pt. Ekakarya Graha Flora). Moneter - Jurnal Akuntansi Dan Keuangan, 2(2).

Makmur. (2015). Strategi Pemasaran Dalam Meningkatkan Volume Penjualan (Studi Pada S-Mart Swalayan Pasir Pengaraian). 3.

Mardiasmo. (2018). Perpajakan Edisi Terbaru 2018 (XIX; Maya, ed.). Yogyakarta: C.V Andi Offset.

Riftiasari, D. (2019). Pengaruh Restitusi Kelebihan Pembayaran Pajak Pertambahan Nilai Pada Kantor Pelayanan Pajak Pratama Jakarta Penjaringan. Moneter - Jurnal Akuntansi Dan Keuangan, 6(1), 63-68.

Risyana, R., \& Suzan, L. (2018). Pengaruh Volume Penjualan Dan Biaya Operasional Terhadap Laba Bersih (studi Pada Perusahaan Manufaktur Makanan Dan Minuman Yang Terdaftar Di Bursa Efek Indonesia Periode 2014-2016). eProceedings of Management, 5(2).

Rustami, P., Kirya, I. K., \& Cipta, W. (2014). Pengaruh Biaya Produksi, Biaya Promosi, Dan Volume Penjualan Terhadap Laba Pada Perusahaan Kopi Bubuk Banyuatis. E-Journal Bisma Universitas Pendidikan Ganesha, 2(1-9).

Salman, K. R. (2017). Perpajakan Pph dan PPN. Jakarta Barat: Indeks Jakarta.

Saragih, H. (2017). Analisis Faktor Pendorong Pemasaran Ekspor Dan Pengaruhnya Terhadap Peningkatan Volume Penjualan Pada Pt. Perkebunan Nusantara li (Persero) Medan. Jurnal IImiah Methonomi, 3(2), 149-163.

Wijaya, D., \& IRAWAN, R. (2018). Prosedur Administrasi Penjualan Pada Usaha Jaya Teknika Jakarta Barat. Perspektif, 16(1), 26-30. 